\title{
Partnerships and Charter Schools: Contrasts in Canadian Reform
}

\author{
Samuel Mitchell \\ University of Calgary
}

\begin{abstract}
This paper draws on European views of partnerships that stress policy implications for change rather than financial contributions to an existing system. In North America, critics rant against business influences, but partnerships can transform an inner-directed system. Charter schools need to be related to partnerships. In Canada, unlike the United States, charter schools are strongly resisted by education professionals. Cultural traditions account for the drastic differences between Canadians' and Americans' reaction to charter schools and the varying perceptions of partnerships between Europeans and North Americans.
\end{abstract}

Key words: charter schools, reforms, parnerships

\section{RESUMEN}

Este artículo se nutre en a las perspectivas europeas acerca de las alianzas y asociaciones económicas en educación que acentúan más sus implicaciones políticas de cambio que su contribución financiera a un sistema existente. En Norteamérica, los críticos despotrican contra las influencias comerciales, pero las alianzas vienen a transformar un sistema internamente dirigido. Las escuelas estatutarias requieren vincularse con este proceso. En Canadá, a diferencia de lo que ocurre en los Estados Unidos, los profesionales de la educación se oponen fuertemente a las escuelas estatutarias. Las tradiciones culturales ayudan a explicar las profundas diferencias de percepción de estas escuelas en ambos países, así como las distintas posturas sobre las alianzas en Europa y Norteamérica.

Descriptores: escuelas de carta, reforma, asociaciones

\section{RÉSUMÉ}

Cet article met à contribution des vues européennes sur les partenariats qui mettent en relief leurs implications politiques pour le changement plutôt que leurs contributions financières à un système existant. En Amèrique du Nord, les critiques déclament contre les influences des affaires, mais les partenariats transforment un système individualiste. Les écoles à charte doivent être lièes aux partenariats. Au Canada, à la différence des Etats-Unis, les professionels en éducation résistent fortement les écoles à charte. Des différences culturelles expliquent les différences radicales entre les réactions des Canadiens et celles des Américains envers les écoles à charte et les perceptions variables des artenariats entre les Européens et les Nord-Américains.

\section{Mots-cléfs}

ecoles à charte, réforme, parternariats 


\section{Introduction}

Dartnerships And CHARTER SCHOols involve the question of whether schools are 1 able to change society. Partnerships lead to a reconstruction of society when broad alliances are built. Charters challenge the professionals in school administration, but are limited unless they have a base of popular support. Charters are caught in the longstanding game of adapting American innovations to Canada's different setting.

\section{Partnerships as an Alternative}

As can be clearly seen from ... depiction of so-called Global Policy Networks, partnerships will be the single most important governance innovation in the coming years (Zadek, Hojensgard \& Raynard, 20oI, p. 26).

The authors of this statement are at the Copenhagen Centre, which is supported by the Danish government to study alternatives confronting those in the new economy. Technology is rapidly eliminating boundaries of space, time, and knowledge. With technological competition is a desire among the leaders in the race to assert corporate citizenship. The Copenhagen Centre encourages these leaders to see partnerships as a basis for business people's sense of civic responsibility.

Programs for concern and care are linked to an enhanced role for associations, or nongovernmental organizations that represent the interests of the dispossessed. The triangle among community organizations, businesses, and governments creates ties between winners and losers. Partnerships are the basis for these links. The new partnerships are:

People and organizations from some combination of public, business, and civil constituencies who engage in voluntary, mutually beneficial, innovative relationships and activities to address common social aims. (Zadek, Hojensgard \& Raynard, 200I, p. 25).

Although unrecognized by Canadian educators, the European description of community partnerships addresses the same issues raised in educational conflicts in North America. While reducing educational expenditures, Canadian and American governments support the rush to advanced technology, new required courses in response to business and technical needs, and innovative projects that link education with technology, science, and business (Mitchell, in press).

Technological competition and concern for standard test results at the school level have in some cases led to relational difficulties between successful students and their less successful peers. Student massacres, such as Columbine, dramatize these problems. New programs aim to adjust students to their stressful environments. What churches call pastoral care emerges in the new endeavors of caring, providing conflict resolution, and offering social services. 


\section{Differences Among Partners}

The twin changes of competition and community service are brought to schools through partnerships. In North America, there are different committees for each kind of partnership. Teachers think of partners only as businesses they may call on to provide money or resources (Mitchell, 1996). Most teachers only see financial contributions made by business; they do not believe that business partners help to educate children. Teachers and others see that students are happier and sometimes excited when involved with partners. Corporate public relations and individual businesspeople, such as Doug Baldwin when he was CEO of Esso Resources, mesmerize students and educators (Corporate-Higher Education Forum, 199I).

Broader partnerships fill many of the gaps in schools, whether in social services or the arts (National Association of Partners in Education, 20oI). Who would challenge the right of parents, senior citizens, community members, artists, social and health professionals, or university professors to contribute to public education? Unlike businesspeople, these other partners provide services and ideas for education. When businesses are treated as similar contributors, new programs develop for social and educational aims, such as improving the environment (Mitchell, in press).

As a group, one of the most important partners is lawyers, because they are able to involve other businesspeople and professionals in supporting schools and engaging in dialogue. The Galileo project in Alberta, Canada, has two law firms representing it as it attempts to combine technological change with student-centred education (Mitchell, in press). Lawyers help bring organized projects into existence by drafting the articles of incorporation. Lawyers are involved with top-level meetings of governors or ministers of education and business leaders, and they develop the links for continuing local partnerships. One lawyer, David Hornbeck, planned Kentucky's total reform of education from kindergarten to college. He became superintendent of Philadelphia's besieged urban system, and has influenced many organizations and local reform efforts (Mitchell, 1996). During the I990s, lawyers and accountants organized to support educational reform in Chicago.

Unlike lawyers, scientists are interested in new or abstract ideas about how to improve teaching and curriculum. At the University of Calgary, scientists participate in a program in which they help teachers in city schools. Science educators place an emphasis on individual and corporate partners to improve classes in their area (Mitchell, in press). In Washington, D. C. Nobel prizewinners go into the schools to act as resources for teachers (Mitchell, 1998). Aside from lawyers and scientists, many specific partners enhance schools and teaching.

\section{Power}

The pervasive ability of partnerships to change ideas and relationships is understood by one Canadian organization, the Corporate Higher Education Forum. The Forum sees power as including both knowledge and direction. The Canadian organization brings together an "interface" of business and educational leaders to hear "advisories" on how education is threatened, similar to a weather alert (Mitchell, 1996, pp. II6-II7). The 
American model on which the forum is based, the Business Higher-Higher Education Forum, does not advocate this network approach where knowledge becomes a part of power. The Forum's interpretation is similar, but unrelated, to the theories of Foucault (I977).

The Canadian Forum advocates matching business donations to government grants. They want businesses to "monitor" the grants they give universities, while encouraging universities to work together. Other partnerships attempt to magnify or multiply their influence. Foundations are interested in seeing their grants matched, three or four fold if possible. In North Carolina, The Kenan Institute lobbies state legislatures to match its own grants while persuading one or more foundations or business groups to match their grants (Mitchell, 200o).

Multiplying influence requires changes in several institutions. The Europeans see the resulting partnerships as a way to achieve greater equity in society (Copenhagen Centre, 1999). Shell Oil has developed an initiative to support a dozen or more schools where each school receives support from local businesses as well as Shell (Clearinghouse on Educational Management, n.d.). When varied organizations are involved, educational change evolves.

These emerging partnerships involve people, ideas and networks of contacts. At this point, partnerships become the unseen hand that guides individual schools and school districts. Partnerships will evolve if they continue to bring diverse people together with related ideas. School systems debate individual partnerships and partnership policies when they are established. Later, partners develop their own policies that are not reviewed by schools, school boards, or departments of education.

Partners are not seen as a threat by those who think they control the educational system. Some cries against business influence are raised for those innovations that represent business or "bottom line" thinking (Mitchell, I996). Occasionally, groups try to persuade companies to change their policies. In Calgary, students and teachers criticized Shell Oil for its complicity in the death of a Nigerian poet. The company terminated its partnership (Mitchell, 1998).

Although business partnerships are accepted, they may be a Trojan horse. Other possible partners may not be considered, such as churches, unions, or environmental organizations. Once established, no partnership is reconsidered. Sunset legislation would require the termination of any partner who is not contributing to education. Partnerships need to move beyond the criteria of social acceptability or political correctness.

\section{Minorities}

In North America, partnerships involve issues of placing difficult students into projects. Business partners provide work or incentives for at-risk students to stay in school. Minnesota Mining and Manufacturing is unusual in supporting a school for single mothers in Minneapolis. Nonprofit organizations are involved with schools, particularly in Minneapolis and Milwaukee, for social reasons. Businesses do not deal with potential or actual at-risk students in elementary grades, but community groups support younger students through adult mentors in early education (Mitchell, 1996). 
In the United States and Canada, there are efforts to improve the status of minorities, but these are not related to partnerships or joint activities. Because of tax incentives in the United States, businesses such as MacDonald's develop programs to hire special education students. Canadian business leaders, such as John Ballheim of the DeVry Institute, want similar legislation north of the U. S. border (Mitchell, I998). Because of Canada's policies, some corporate foundations, such as the one established by Amoco, do not make grants in Canada.

In Europe, community partnerships supplement the efforts of government to establish equity in society. Banks and community organizations encourage women to become operators of tourist businesses in Greece, where they have had few opportunities in the past (Copenhagen Centre, 1999). Partnerships promote opportunities for the disabled, new immigrants, residents of remote or rural areas, and those who have multiple handicaps. In North America, partnerships do not deal with these issues.

Ironically, inequality is the most striking issue raised concerning charter schools. The ghosts of elitism, or private schools within public systems, frequently appear. In the United States, the absence of special education students in charter schools increases the cost to the public systems to carry the high costs of disabled students. In Canada, special education students were denied admission to French immersion programs, and although this has now changed, it was not a major issue (Mitchell, I990).

The Canadian options, such as French immersion, are accepted as an extension of the dual religious system, but separate independent schools, such as charters, are not. Americans now see equity problems with charter schools because of their location and rapid growth (Associated Press, 1999). With a small number of schools and students randomly selected, there is no equity issue in Canada. Since they live in the shadow of America, Canadians think they have American problems when they do not.

\section{Opposition to Change}

In the absence of American-style court actions challenging inequality among school districts, Alberta took financial control away from public school boards in order to provide greater equalization. The attacks on school boards, similar to the broader campaign to reinvent government, are examples of direct American influences. In Canada, school boards lost their ability to tax, and were either eliminated entirely or the remaining governors saw their influence decline as a result of power given to school-based management or school councils.

The loss of money to school boards caused by the transfer of government grants to charter schools is important because of the financial restraints that governments place on the boards. Governments and school boards place new responsibilities on principals and middle level administrators who may have to either compete with charters or organize them. Unions fear the loss of members. Charter schools challenge those who control the system or who must work within it. The system is precarious!

When charter schools combine with technology to cross existing school boundaries, the screams heard in response are like an attack from Dracula! School boards are not only losing financial support for their students, but the intruder is in their house 
(Woodhall, 2000; Woodhall, 200I). Virtual schools are an attractive supplement for those who want home schooling and who seek to avoid the "negative socialization" of schools. The Nechako school district of British Columbia, including Vanderhoff, has a program for providing computers and instructional support to assist home schoolers in their own district. This "electronic busing" program spread across the province, but so did the opposition (Donaldson, 200o). The concoction of charter schools, virtual education, and home schooling is a brew so potent that existing educational administrators may die from it.

Although charter school advocates may gloat in the demise of their opponents, the feud needs to be ended. In today's schools, there are increasing shortages of administrators because of these demands, but charter schools burn out principals at an incredibly high rate. Canadian principals fight to make their voices heard over the cries in this battle.

Proponents of public schools claim that they are defenders of democracy when a small minority of eligible voters cast lots in school board elections. Since their continuing support is necessary for survival, charter schools involve their supporters, including school maintenance. How can other schools generate as much support as charter schools? The right to establish charter schools is a part of democracy until the regular schools amend the constitution to serve their own interests.

Opponents claim that charter schools are making unreasonable demands when they expect parents to contribute to education. The positions of Plato and Rousseau are forgotten. Plato feared those who taught for pay when the relationship had to be close. Rousseau believed nature required the parent to assume responsibility for the education of one's own child. Research on the effects of parents over teachers in learning should be considered, so that educational innovations could relate to differences among parents as well as their common expectations (Marjoribanks, 1979).

Innovations developed by educators are the ones that shock community expectations (Immerwahr, Johnson \& Kernan-Scholoss, I99I). When will the community become more than input for the professionals? Can anyone answer for the professionals' making rural schools into the image of their city cousins, including consolidation? It has been suggested that rural areas need charter schools for protection (Collins, I999; DeYoung \& Boyd, I99I). Can democracy exist within schools, or schools as a part of society, when citizens are treated as clients?

While educational monopolies are often discussed in the United States, their power is asserted as a life and death struggle in Canada. The combination of existing alternatives and concentrated opposition to charter schools defines the Canadian position. While the United States expands its charter schools into the thousands, one province in Canada, Alberta, has barely a dozen. Originally, charters could be approved by the provincial department of education. Legislation in Alberta is being amended so that schools boards must agree to the charters, unlike the multiple sources of legitimacy in American states (J. McCarthy, personal communication, June 26, 200I).

By making charters into alternative programs, the Canadian approach is more organized. The Americans discovered through trial-and-error that charter schools need a resource centre because they lack a central office for guidance (Donsky, 2000). 
The Canadian Charter Schools Research and Professional Development Centre provides assistance and initial funding to schools in Alberta and to inquiries about similar efforts across Canada (www.charterschools.ca). American charter schools experience many problems with management and financial arrangements, and they are assisted by private firms.

The Canadian Charter Schools Centre is directed by John McCarthy, the former Superintendent of the Calgary Catholic School system. Dr. McCarthy was selected by Helen Raham from the Society for the Advancement of Excellence in Education, which, in turn, raised money from a number of foundations that found charter schools attractive (Robert O'Reilley, personal communication, July 23, 200I). These foundations include Lotte and John Hecht, Marigold, and Max Bell. Reportedly, individual charter schools would have chosen a different director.

Dr. Gereluk (1996) believes the more centralized Canadian approach needs support from government. Americans are seen as having governmental support and university policy institutes that provide direction; Canada lacks this kind of support. Leading American advocates do not call for government assistance; such support is the opposite of their ideological position (Finn, Manno \& Vanourek, 2000). States, such as California and Arizona, that have policy institutes, do have a large number of charter schools, but the relationship is obscure. The perception of government support as a key is an attempt to find the silver bullet that would increase public support for charter schools.

Alberta, which is the only Canadian province to support charter schools, gives sporadic support. This province depended on one minister, Halvar Johnson, and one bureaucrat, Ron Rabiuk (Gereluk, 1996). When the minister of education was changed and the bureaucrat died, there was no one within government to advocate for charter schools. There is no parent or public demand for charter schools. The Canadian Centre attempts to increase the number of schools, but principals of existing schools disagree with the centre about policy. Proposals for charter schools are being accepted by the province of Ontario, but the supporters of charter schools are uncertain how the government will proceed or the approach that they will take there (Helen Rabham, interview, August IO, 200I). Unlike the American traffic in charter schools, their parallel in Canada is a search for a hidden passage.

\section{The American Connection}

These differences raise the issue of whether the two neighbouring countries are alike in their educational innovations. Programs related to business partners are similar because the companies involved are closely linked. Although Canada follows the American models, partnerships involving the arts, social welfare, and health are interpreted differently. The power interface within Canada affects these relationships.

Canadians react to American innovations in a way that assures control by the powers-that-be. Calgary copies Chicago's arts partnership program, and has obtained permission from Chicago to use the same acronym. The Chicago program is decentralized into eleven community groups. In contrast, Calgary has one office, roster of 
artists, and policy (Mitchell, 2000). In I995, an opportunity to meet with Chicago and other partners for an Annenberg foundation grant of \$IO million was declined, since the preference was to raise money in Calgary. Similarly, the province of Saskatchewan earlier plagiarized its educational plan from the American proposal, a Nation at Risk (Stewart, I986). In spite of its strict start, Saskatchewan's practice is liberal, including its integration of the arts.

The contradictions in attitudes towards the United States are segregated through reliance on authorities. Direction is expected from experts while resentment is directed towards them. There is little direct interaction across institutional lines. In Calgary, the University of Calgary is not involved as a business partner with the schools in spite of the fact that it is the city's fourth largest employer. Although it is a major source of live performers, the same university is not involved in programs for the arts, nor is it involved in programs for health or social service despite operating the city's largest hospital. The sources of inspiration are kept apart in Calgary partnerships. These spheres are not so separate in the United States.

The histories of the two educational systems are different. Canada is linked to the stability of European models, while the United States creates a booming, buzzing confusion of new innovations (Poignant, 1969; Tomkins, 1986). Business in both countries influences the schools more than any other institution. In the United States, one retired oil executive, Lovett Peters, offered to take over the schools and return them with \$I million if he did not produce improvements (Vaishnave, 2000). A school superintendent, Wilfredo Laboy, resentfully declined the offer. He believed Mr. Peters should give them the money to improve the schools. In Canada, a direct offer would be unlikely, and there would be no expectation for improvement over such a brief period of time.

\section{Evaluation as a Control}

Although educators will not always bow to business leaders, business does influence educators' thinking. Where else do new views such as the "bottom line" of evaluation or signing bonuses for teachers come from? In the distant past, religion would have had a similar influence. Moreover, the family as a foundation of community has retained global and personal meaning for those in any organization trying to get people involved.

Governments follow the business model and leave it to local school or community groups to develop more personal ties. The state has direct control over the schools, but it will loosen its ties in exchange for measured results from schools (McDonnell, 1994). Many American states require charter schools to show improvement over regular schools or their own previous records. Alberta requires only that goals be measured.

Neither country is concerned in practice about academic progress because school closures result from financial problems or mismanagement. The measurement requirement may be only a way of appeasing ideologues. No such requirement is made of partnerships. Measurement is involved as a source of legitimacy when there is controversy. 
Without several concerned constituencies, organizations are likely to juggle the results of evaluations to present themselves favourably. Communities in Schools, a program of social services for schools, reinterprets a negative national evaluation (Mitchell, 1996). The Galef program of arts education eliminated less positive results from an evaluation, which led to the resignation of its research director (Karen DeJarnette, personal communication, April 2, 2000). The director of a study of the Great Books Program, James Davis, pointed out that his sponsor decided on their interpretation before the research report was complete (Hammond, 1964).

European experience suggests that varied partners make evaluations a guide for future action. These evaluations are based on context as well as triggering events. Examples of indicators used by the local partners included the World Bank's Business Partners for Development and the Prince of Wales Business Leaders Forum Assessing the Value. Although these evaluations are those of government and community projects, they involve the "value added" idea that is popular with educators.

Whether a part of the "value added" analysis or not, the critical question for advancing evaluation is to increase the number of partners and the range of their activities. Large business can promote smaller firms and new efforts. Communities can enhance the opportunities of unemployed youth. School partnerships can lead to community reorganization. Rural communities are full of potential partners. An environmental project for students involving the Gulf of Maine includes one school district in Nova Scotia and others in New Brunswick, Maine, New Hampshire and Massachusetts (Mitchell, in press).

\section{Dynamic Partnership}

Americans' preoccupation with measurement and improvement has distinguished them from their Canadian neighbours. A Canadian effective schools project claimed American efforts with the same title were focused on higher achievement scores. The Canadian approach used British research of effective programs to emphasize the process of change as a part of a whole school effort to improve (Mitchell, 1990).

President Bush has proposed annual measurement. His solutions for schools showing no improvement include a private take-over, reconstituting or selecting new staff, or a charter school status. Charter schools become a part of the armoury to force schools to improve. Canadian charter schools are to follow an improvement plan. Canadians are concerned that their schools stay ahead of Americans, but are not aiming at improvement forever.

Idealistic concerns can bring Europeans to combine conflicting groups into a single partnership. The experience of co-determination by labour and management creates a model for later partnerships. Canadian experience makes the reaction to conflict among partners something unexpected. The Europeans and underdeveloped countries combine nongovernmental organizations with businesses and government. The Canadian partnerships of schools are creative when establishing businesses programs within schools; under the business umbrella, nonprofit models are combined with profit models (Mitchell, in press). 
Canadians maintain a separate identity but follow rules that reinforce status differences and cause continuing problems. The Canadian Studies Foundation maintained their own studies and materials, but that foundation collapsed under the weight of provincial differences and bureaucratic red tape (Tomkins, 1986). Bureaucracy is related to plagiarism and copying rather than creation of new alternatives. When American patterns are not followed, Western Canadians follow Eastern Canadian programs, such as a project for mentors for secondary students developed in an Eastern Canadian province (Mitchell, 1998).

One teacher who said, "Any innovations the Americans have tried and found to fail we are sure to adopt," revealed the combination of copying and resentment. Leaders can create new combinations with shared purposes. Three leaders from the university, the symphony, and the school system created a music partnership in Kingston, Ontario, Canada (Mitchell, in press). This program draws on strong grassroots support and recognition that is symbolized by the firing of cannons from old Fort Henry during the climax of the $I 8 I 2$ Overture. The program prospers without foundation or outside support. Leadership prevents American domination, but that domination makes the development of leadership difficult.

Covert resistance leads to a tendency to categorize people and ideas, and are exemplified by divisions between private and public affairs, which underlies the opposition to charter schools, the separation of American and Canadian approaches, the difference between theory and practice and the acceptance or rejection of whole programs for arbitrary reasons. The conflicts immobilize many people when innovations are discussed.

Rationalizations and social distance separate the experts and administrators from teachers and laity. This separation diminishes the possibilities of creative solutions being developed and accepted in Canada. The international elite must endorse most Canadians' cultural developments, since separation and subordination produces insecurity and defensiveness. When ordinary parents, teachers and students meet, they develop innovations within partnerships, but, otherwise, they are lost in the forest of experts.

Although hierarchies are the major problem in developing alternatives to American and expert ideas, Canadians organize these influences in hierarchies. The Information Technology Association of Canada wants business partnership structured in a sequence: efforts at adopting a school at the elementary level, career exploration at the secondary avenues and joint research programs for higher education (Mitchell, 1996). An additional defence is the Canadian tendency not to join associations based outside Canada (Mitchell, I996).

Although Canadian universities vie for international status, a recent training session about how to receive grants from the Social Science Humanities Research Council advised avoiding international references, because they would not write inflated recommendations (Doug Peers, presentation, July 26, 200I). Partnerships allow academics to focus on community effects rather than trading favours among peers in a seminar of navel contemplations. International partnerships, including diverse partnerships, increase the range of thinking. 


\section{Expanding Partnerships}

Most partnerships, like most charter schools, are local affairs. The general problem is how to expand partnerships that involve people and organizations in one community into larger political units. The usual innovations in education proceed from international experts and national meetings of government and business leaders to plans for local areas. Local innovations must be ones that people want most to implemented: community services, business partnerships, and university leagues.

Medical services are a base from which social services can be provided and which different schools are able to be coordinated. In Calgary, schools and public schools, including those with charters, are part of the same coordinated policy, but an earlier program of integrated social services was abandoned (Bonnie Johnson, presentation at University of Calgary, February 19, 2000). Medical and social services are an innovation to develop, expand, and publicize partnerships.

Communities in Schools (CIS), founded in 1972 by Bill Milliken, who regularly associates with American presidents, is a prime example of the development of high profile innovations. CIS was designed for at-risk students: it includes special schools as well as the program for activities within schools. A new special school is added by the National Football League after every Super Bowl. The regular school program is supported by a percentage of recordings or concerts by leading popular artists (Mitchell, 1998). CIS operates through affiliates in Canada and England.

Entrepreneurial innovations seek recognition. A program for retrieving and recycling building materials, Enviroworks, in Kingston, Ontario is developing a network of similar projects after its own work was recognized by the United Nations, the Emperor of Japan, and corporate leaders (Mitchell, in press). Enviroworks looks for partners who are complementary. For nonprofit groups, their students provide consumer research that the partners could not afford, while students gain needed experience. Tourist work gives both the industry and Enviroworks vital publicity. Companies which operate in the same niche, like Home Depot, provide a partner whose support could multiply the educational program across North America.

All partners are not equal. Foundations are apt partners because they want to multiply their efforts; they mobilize the resources of universities to help schools. Professional development schools are one of the links between schools and higher education. The Coalition of Essential Schools (CES), which has a university base at Brown University, links over a thousand schools in the United States. CES assisted the Galileo project in Alberta, when it came under attack during its first project.

Universities, technical schools, and community colleges are important partners because they have educational aims. Businesses and schools are convergent when the staff from both institutions are involved in the same training program. Similarly, teachers and parents who learn about community development and the arts together become an effective advocacy group for schools. The key question is the extent to which partners are involved in a common mission. 


\section{Conclusions}

All partners broaden the restricted vision of educators. In the much-publicized case of charter schools, educators become a sectarian group. The pressures on schools may excuse their behaviour regarding charter schools, but it is difficult to understand why they underestimate the contribution of partnerships. Partnerships provide a basis to achieve equality and participation in education. The Europeans provide examples of cooperation between business organizations and advocacy organizations .

In North America, such cooperation will need support before educators dare to be involved. Once the possibilities are realized, allies can publicize efforts, expand partnerships, and advocate for common causes. Partnership should be a lever for improving social and medical services within schools. Educators are divided themselves about the educational goals of schools. If they can overcome their own conflicts, partners will support their academic efforts.

\section{References}

Associated Press. (1999, February I6). Little difference is found in charter public schools. Detroit News. Retrieved from http://www.detroitnews.com.

Clearinghouse on Educational Management, College of Education, University of Oregon. (n.d.). Trends and issues: Relationships with the community. Retrieved from http:// www.eric.uoregon.edu.

Collins, T. (1999, January). Charter schools: An approach for rural education? ERIC Clearinghouse on Rural Education and Small Schools. Retrieved from http://www.ael.org.

Copenhagen Centre. (1999). New employment partnerships in Europe. Copenhagen: Copenhagen Centre.

Corporate-Higher Education Forum. (I99I). To be our best: Learning for the future (Audio Tape). Montreal: Corporate-Higher Education Forum, I99I.

DeYoung, A. \& Boyd, T. (I99I). Urban school reforms for a rural district: A case study of school/community relations in Jackson County, Kentucky, I899-1986. Journal of Thought, 2I(4), 25-42.

Donaldson, M. (2000). The growth and development of the Nechako electronic busing program. Unpublished paper, University of Calgary, Canada.

Donsky, P. (2000, July 2I). Help on way for charter schools. Atlanta Constitution. Retrieved from http://www.accessatlanta.com.

Finn, C., Manno, B. \& Vanourek, G. (2000). Charter schools in action. Princeton, NJ: Princeton University Press.

Foucault, M. (1977). Discipline and punish: Birth of the prison. New York: Vintage, Random House.

Gereluk, D. (1996). Voices, choice and power: Contested spaces in charter schools. Unpublished doctoral dissertation, University of Chicago.

Hammond, P. (1964). Sociologists at work. New York: Basic Books.

Immerwahr, J. Johnson, J. \& Kernan-Scholoss, A. (199I). Cross talk. New York: Public Agenda Foundation.

Marjoribanks, K. (1979). Families and their learning environments. London: Routledge and Kegan Paul.

McDonnell, L. (1994). Assessment policy as persuasion and regulation. American Journal of Education, 103, 394-420.

Mitchell, S. (1990). Innovation and reform. York, ON: Captus.

Mitchell, S. (1996). Tidal waves of school reform. Westport, CT: Praeger. 
Mitchell, S. (2000). Partnerships in creative activities among schools, artists and professional organizations. Lewiston, NY: Edwin Mellen.

Mitchell, S. (forthcoming). Reforming educators: Teachers, experts and advocates. Westport, CT: Praeger.

Mitchell, S. (in press). Effective partnerships: Experts, advocates, and scouts. Westport, CT: Praeger.

National Association of Partners in Education (200I). Partnerships 2000: A decade of growth and change. Alexandria, VA: National Association of Partners in Education.

Poignant, R. (1969). Education and development. New York: Teachers College.

Tomkins, G. (1986). A common countenance. Scarborough, ON: Prentice Hall.

Stewart, D. (1987). Cutting to the core: Curriculum mishaps in Saskatchewan. In D. Cochrane, (Ed.), So much for the mind. Toronto: Kagan \& Woo.

Vaishnave, A. (2000, September 29). Schools: Thanks a million, but no. The Boston Globe, p. BOI.

Woodall, M. (200o, October 4). Web-based charter school is proposed. Philadelphia Inquirer. Retrieved from http://www.philly.com.

Woodall, M. (200I, April 24). Suit to challenge "virtual” schools. Philadelphia Inquirer. Retrieved from http://www.philly.com.

Zadek, S., Hojensgard, N. \& Raynard, P. (200I). Perspectives on the new economy of corporate citizenship. Copenhagen: Copenhagen Centre. 
104 Encounters/Encuentros/Rencontres 